\title{
DEWEY'S THEORY OF VALUE
}

\section{I}

I NHE BELIEF that John Dewey's theory of value is $I$ not only the hub of his philosophy, but that it also constitutes the chief contribution of Pragmatism to current philosophy, I wish, in this paper, to show what Dewey's theory of value is, to indicate its relations and significance, and to adduce corroborations of the theory from certain unexpected quarters.

No one can hope to understand Dewey's theory of value who does not grasp rather fully the meaning that he attaches to the term "experience." Such an intellectualistic penumbra hangs over the word that some readers never understand that Dewey means other than what they would mean if they used the word in a similar connection. That he does mean something different, and something more, he has emphasized most vigorously in the introduction to his Essavs in Experimental Logic. It seems that Professor Dewey himself did not for a long while get fully clear the significance of the distinction; and he gives Mr. S. Klyce credit for pointing out to him this and "other indispensable considerations." Upon this point Dewey explains: "Our words divide into terms and into names which are not (strictly speaking) terms at all, but which serve to remind us of the vast and vague continuum, select portions of which only are designated by words as terms." 1

${ }^{1}$ Essays in Experimental Logic, p. 8n. 
Now the word "experience" and such other words are not terms at all; they are what Mr. Clyce calls "infinity and zero" words. As opposed to such a word as "desk" (which is a term referring to a definite object, on which consciousness is or may be focussed), the word "experience" refers to the fringe or penumbra of the situation in which "desk" or any other term is the focus. As Dewey says: "The word 'experience' is . . . a notation of an inexpressible as that which decides the ultimate status of all which is expressed; inexpressible not because it is so remote and transcendent, but because it is so immediately engrossing and matter of course." ${ }^{2}$ Such a word, then, connotes what is before and after and around that which at any given time is denoted. "I shall only point out," says Dewey, "that when the word 'experience' is employed in the text, it. means just such an immense and operative world of diverse and interacting elements." 3

Experience, as this will indicate, is a much broader term than knowledge. Instead, therefore, of putting the auestion as some philosophers have, i. e., whether there are different ways of knowing, we must cease begging the auestion and ask whether there are not different ways of experiencing, of which knowing is only one. We certainly must be content to put the matter in this way, if we are to understand Dewey; for Dewey makes this point in wholly unambiguous language. "Knowing," says he, "is one mode of experiencing, and the primary philosophic demand . . . is to find out what sort of an experience knowing is-or, concretely how things are experienced when they are experience as known things. . . . To assume that, because from the standpoint of the knowledge experience things are what they are known to be, therefore, metaphysically, absolutely, without qualification, everything in

2 Essays in Experimental Logic, p. 10n.

${ }^{3}$ Essays in Experimental Logic, p. 7. 
its reality (as distinct from its "appearance," or phenomenal occurrence) is what a knower would find it to be, is from the immediatist's standpoint, if not the root of all philosophic evil, at least one of its main roots." 4

While Dewey has carried the analysis of experience somewhat into detail in the foregoing citation, we may rest, for the purpose of this paper, in his usual dichotomy. If we analyze the various aspects of our experience, we find on the one side what Dewey refers to variously as "appreciation," "realization," "direct, non-cognitive doing-suffering," and on the other side what he refers to as "reflection," "thinking," "cognition," "judgment." Experience, of its own intrinsic nature, falls thus into a dualism-qualitative at least-and the nature and relation of these two parts constitute both ethics and logic. Perhaps nowhere better than in Democracy and Education has Dewey plainly set over against each other these two aspects of experience.

"To value means primarily to prize, to esteem; but secondarily it means to apprize, to estimate. It means, that is, the act of cherishing something, holding it dear, and also the act of passing judgment upon the nature and amount of its value as compared with something else. To value in the latter sense is to valuate or evaluate. The distinction coincides with that sometimes made between intrinsic and instrumental values. Intrinsic values are not objects of judgment, they cannot (as intrinsic) be compared, or regarded as greater and less, better or worse. They are invaluable and if a thing is invaluable, it is neither more nor less so than any other invaluable. But occasions present themselves when it is necessary to choose, when we must let one thing go in order to take another. This establishes an order of preference, a greater and less, better and worse. Things judged or passed upon have to be estimated in relation to some third thing, some further +Infuence of Darwin on Philosophy, p. 229. 
end. With respect to that they are means, or instrumental values." 5

From this quotation as a basis, Dewey's theory of value may, I think, be fairly summarized in the four following theses:

\section{II}

I. Experience, which furnishes the context of all values, is largely non-cognitive. ${ }^{B}$ It is well to emphasize this non-cognitive basis of cognition itself; for upon this plane of experiencing lie most of the contents of our living. Here are included our loves and our hates, our eating and our sleeping, our friendships and our animosities, our illness and our health; here too are the fine arts $;^{7}$ here the dumb gladness that welcomes the dawn, the quiet contemplation of the sun's trailing glory at eventide, and the silent watching of the passing night. This is the primal and ever the larger aspect of human life. It is the good-in-itself, from which reflection rises and for whose sake reflection exists as an instrument.

2. Experience becomes cognitive only when incom. patibilities demand more than mere appreciation for their successful resolution. ${ }^{8}$ Dewey is primarily interested in intrinsic values, in the appreciative life described above. Indeed, no living being, thinks he, ever becomes interested in "extrinsic" value until he must in order to save and extend some of the "intrinsic" content of his appreciative life. Then judgment comes into play as añ instrument that is justified by resolving the difficulty back into a situa-

${ }^{5}$ Democracy and Education, p. 279.

8 "Experience is primarily an active-passive affair; it is not primarily cog. nitive." Essays in Experimental Logic.

7 "For Dewey's feeling estimate of the place of art in life. see Reconstruc tion in Philosophy, p. 212. Cf. Human Nature and Conduct, p. $159 \mathrm{ff}$.

8 "Difficulties occasion thinking only when thinking is the imperative or urgent way out. . ." Reconstruction in Philosophy, p. 139. Cf. Democracy and Education, p. 280. 
tion that permits intrinsic goods again to become possible. If judgment begins building upon itself a hierarchy that forbids the energy of life to dip again into its stream, it meets Nemesis upon its upward way, who robs it of its vaunted glory and leaves it quite inane. "In fact, 'good" is an empty term unless it includes satisfactions experienced." 9

3. Such adjustment ${ }^{10}$ arises from, exists for the sake of. and dips again into, non-cognitive experience. Thinking becomes thus an instrument, but an indispensable instrument, for the continuous preservation of the values for which it exists.

4. Moral judgments do not discoz'er walue outside experience, but reconstruct and create values zeithin expericuce. Let it be carefully borne in mind what has been said about the genesis of judgments of all kinds. Value juclgments are not unique, as Dewey thinks, save in that they deal with a content that in direct experience was valuable. Value judgments arise out of a situation made embarrassing by a conflict between two equally valuable parts of experience or out of some other equally unsatisfactory turn of experience; and the judgments are but citations of what seems necessary to make experience once more satisfactory. Judgments are-if one wishes to put it so-discoveries of what, under the circumstances, one ought to do, if he is successfully to resolve the unsatisfactory situation. The judging process is not only the discovering of what is to be done, but it is also the first step of the action itself. It is not a discovery of something already existent (though it has such as its data), because the situation to which the judgment looks as an end that is to resolve the maladjustment, has never yet existed and would not come to exist but for the process of action which is initiated by the judg-

- Democracy and Education, p. 412.

10 "It comes after something and out of something. and for the sake of something." Essciys in Experimental Logic, p. 75 . See also Ibid., p. 36. 
ment itself. ${ }^{11}$ The restored equilibrium is the creation of the active life through the judgment as its tool. "At whatever risk of shock," thinks Dewey, "this doctrine should be exposed in all its nakedness. To judge value is to engage in instituting a determinate value where none is given." The contention that judgments of value are practical includes two points: "one, that the judgment of value is never complete in itself, but always in behalf of determining what is to be done; the other, that judgments of value (as distinct from the direct experience of something as good) imply that value is not anything previously given, but is something to be given by future action, itself conditioned upon (varying with) the judgment." ${ }^{13}$ For an ill person to decide that it is well for him to see a doctor is but for him to take the first step in the creation of the good of his then situation, i. e., the seeing of the dortor, a good that but for his judgment would never conic io exist at all.

It is well for Dewey to insist upon the practical nature of judgments of value: for if he can establish that fact, he has not only added something to our understanding of such judgments, but he has also in a way as effective as it is indirect warded off from his general theory criticisms from both idealists and realists. From both schools alike have come charges of subjectivism against pragmatism. Those who incline toward subjective idealism have wished to claim Dewey; those who have espoused the cause of objective idealism have joined with the realists in saying that Dewey is a subjectivist. Only in so far as Dewey's general theory of knowledge is involved in his theory of value am I interested here in discussing his views on epistemology. Dewey has elsewhere attempted to show that those who, with Bertrand Russell, state the existence of

11 Essays in Experimental Logic, pp. 358-359.

12 Ibid., p. 368.

13 Ibid., p. 361. 
the world as a logical problem are but unconsciously chasing their own shadows; for the very words in which they are forced to state the problem show that they have already answered the question in the affirmative before the question is put. ${ }^{14}$ But as regards the epistemological gulf in the study of value, if it were true that there is such a thing as the objective world and such a thing as the subjective world, and the integrity of the subjective were determined by its "correspondence" with the objective, then it were a most serious charge against Dewey to say that he is a subjectivist. For in the field of value, it means that he proclaims what could be hardly less serious than moral solipsism. To both the idealist and the realist who feel that they must have the objectivity of moral judgments before their judgments can command respect, Dewey seems, if not himself corrupt, at least a corrupter of youthful America. ${ }^{15}$

How, then, does Dewey escape the seriously meant charge of denying the objectivity of value? He escapes by pleading a change of venue, by denying the jurisdiction of the court. "I can but think," says he, "that much of the recent discussion of the objectivity of value and of valuejudgments rests upon a false psychological theory. It rests upon giving certain terms meanings that flow from an introspective psychology which accepts a realm of purely private states of consciousness. . . To refer value to choice or desire, for example, is in that case to say that value is subjectively conditioned. Quite otherwise, if we have steered clear from such a psychology." 16

Once granted that there is another way of approaching the problem than the subjective-objective route; i. e., once granted that not all experience involves the knowing relation, one will have little difficulty in seeing that Dewey's claim that value-judgments are practical, is an effective

14 Logic, p. $281 \mathrm{ff}$.

1s W. H. Sheldon, The Journal of Philosophy, 18:309-20.

${ }^{18}$ Essays in Exp. Logic, p. 364. See also Democracy and Education, p. 195. 
refutation to either the claim that they are subjective or the claim that they are objective. Even though one himself does not accept all that Dewey puts into his conclusions, he must then admit, I think, that Dewey is at least consistent with himself. This robbing of the subjective-objective problem of its meaning is by no means the least thing for which students of value have to thank Dewey, as I see it. So long as we did not see that value-judgments arise out of a specific non-cognitive situation in need of adjustment, that it is the first step in an action that seeks to resolve the difficulty, and that it dips then to a nonreflective level where intrinsic goods are again possibleso long did we wander from the meaning of concrete experiences and lose ourselves in the attempt to discover the good, überhaupt.

This has been the besetting sin of philosophers beginning with and including Plato. ${ }^{17}$ But whether they have been on the search for "the end, the summum bonum, the final goal" or for inflexible standards with which to sound conduct for "eternal values," they have uniformly returned empty-handed. The sufficient reason why they have failed, says Dewey, is that "in the abstract or at large, there is no such thing as degrees or order of value." "It is reasonable to believe," says he in another place, "that what holds moral knowledge back is above all, the conception that there are standards of good given to knowledge apart from the work of reflection in construction of methods of action." ${ }^{18}$ The reason for this faith on Dewey's part he elsewhere indicates in these words: "Physical knowledge did not as matter of fact advance till the dogma of models or forms as standards of knowledge had been ousted. Yet we hold tenaciously to a like doctrine in morals for fear of moral chaos." 10 Just as the abolition of this point of view

${ }^{17}$ Infuence of Darwin on Philosophy, p. 50.

18 Logic, p. 382.

10 Ibid., p. 381. 
in the natural sciences has led to such phenomenal widening of the boundaries of our knowledge, even "in like fashion," thinks Dewey, "we may anticipate that the abolition of the final goal and the single motive power and the separate and infallible faculty in morals, will quicken inquiry into the diversity of specific goods of experience, fix attention upon their conditions, and bring to light values now dim and obscure." ${ }^{20}$ Renouncing, then, once for all "the diversion of intelligence from discrimination of plural and concrete goods . . . which has done more than brute love of power to establish inequality and injustice among men," ${ }^{21}$ and leaving henceforth to "poetry and to art, the task (so inartistically performed by philosophy since Plato) of gathering together and rounding out, into one abiding picture, the separate and special goods of life," ${ }^{22}$ we shall "converge all the instrumentalities of the social arts, of law, education, economics, and political science upon the construction of intelligent methods of improving the common lot." ${ }^{23}$

\section{III}

It is this ringing call for man to live in his own world and this justification for his so doing, that constitutes the essence of Dewey's philosophy. While others have cried "lo, here; lo, there!" Dewey has continually insisted that the kingdom of good is within human experience. It is difficult to see why this course should need to be emphasized. For other-wordliness is supposed to have passed with many other anemic beauties of the mediaeval world. And this is all that Dewey is really saying in his theory of value: values are immanent in human experience. Take them for what they are: if they are many, so much the better; if 20 Darwin, p. 70.

21 Ibid., p. 75.

22 Ibid., p. 71.

23 Ibid., p. 69. 
they are found within classes that aforetime were vulgar, judge the classes by the values, rather than the values by the classes. When Dewey insists that values are here, he also indicates the very important social doctrine that they are everyzuhere here. No class has a monopoly upon them; if so, the chief task of man is to see that monopoly ended. To make values common to all men, to deepen them, and to guarantee them-this is the threefold problem common to philosophy, to science, to government. This is the Problem of Man. The first step in the solution of the problem is the whole-hearted recognition that values are immanent in human experience, rather than secluded in some transcendental or conceptual realm accessible to common men only through priestly or philosophic or governmental intermediaries. It is this recognition that philosophers have often failed consciously to make. I say "consciously," for since all the values there are, are really in human experience, it would not be marvelous if philosophers were found, when off guard, to speak more wisely than when in the cold ecstasy of philosophic sophistication. With this hypothesis let us ramble a bit in the out-of-way preserves of the two modern system-builders.

Of all moderns who have found human experience most lacking, whether taken as a whole or by parts, F. H. Bradley perhaps comes first. His Appearance and Reality succeeds so fatally well as practically to mean for man, as Schiller facetiously suggested, the disappearance of reality. Begin where he will in the evaluation of human experience, Bradley can find nothing that is not shot through and through with inadequacies, contradictions, infinitude. "Surely," he would say, "nothing here can be thought to be finally valuable." It is only in the Absolute that value can be found (though he even quibbles at predicating good of the Absolute). ${ }^{24}$ Here, it would seem, is a complete 24 Appearance and Reality, p. 411. 
antithesis to Dewey's theory of value; for Dewey finds all values in human experience, whereas Bradley finds none possible in it. If human experience has any values at all, they can appear as valuable only in the Absolute, never in themselves. Here we see a traditionally recurring effort to belittle man's world carried through to its logical completion. Man's world remains good only for its bads.

But the Absolute, in relation to which alone can anything else possess value, gets its value from its reconciling nature. The Absolute seems the complete embodiment of the seventh beatitude: in it all the contradictions of a bedeviled world are set right. In it all questions cease from troubling and all problems are at rest. But how is this consummation (so devoutly to be wished!) attained? It is attained by the abolition of thought (relationally infected thought!); for the Absolute is not only trans-temporal, trans-spatial, but trans-rational as well. ${ }^{25}$ If solution of contradictions is the great end that the Absolute attains, then absence of reflection is the great means through which the great end is reached.

At this stage, the question will inevitably arise: If the solution of contradictions is the end to be sought, and the means to its solution is the absence of thought, then why go to such length to attain what is already present at the outset? For unless the term "thought" be used in such a double sense as really to destroy its meaning, thought certainly does have its genesis in just the sort of situation that Bradley thinks it attains only at the end. The appreciative realm in which we daily live, move, and have our being is, as such, non-reflective; and being nonrational, it has neither contradictions nor problems. These do arise, but their birth means its death. We do not value and evaluate the same object at the same time. Whether one recognizes it or not, it is the deep concern with which 25 Appearance and Reality, p. 172. 
he views the interruption of his a-logical experiencing by a hostile environment, a concern growing out of the unspeakably, the un-rationally profound significance this mode of experiencing has for his life,-it is this concern, I say, that leads to such persistent efforts, as Bradley's, to think out the contradictions and restore the values. In his description of the Absolute, Bradley has described with vivid accuracy a genuine part, the most meaningful part, of human experience. In a paradoxical epigram, halfplayfully placed in the preface to his Appearance and Reality (an epigram apparently evolved in a moment of detached musing), Bradley has done more than in the entire book that follows accurately to analyze human experience and precisely to indicate the relations between its parts. Says he: "To love unsatisfied the world is a mystery, a mystery which love satisfied seems to comprehend." ${ }^{28}$ (Italics mine.) Not even the incorrigibly intellectualistic sentence $^{27}$ with which he closes the excerpt can obscure the genuine significance that Bradley himself finds in immediate experience, such as is represented by "love." Indeed, Bradley's epigram indicates in a sentence Dewey's own theory of value. Bradley's naive insight at the beginning states, it seems to me, quite as intelligibly as does his much belabored dialectic that follows for six hundred pages, the nature of thought and reality and their relations to each other. Since Bradley graciously leaves to the reader "how seriously" ${ }^{23}$ he shall take that epigram, I for one have long preferred to take it more seriously than I do the remainder of Appearance and Reality.

Another corroboration of Dewey's analysis and emphasis that comes from quite as unexpected a source and comes, even as in Bradley's case, from a moment of relaxation

${ }^{20}$ Appearance and Reality, p. xv.

27 "The latter is wrong only because it cannot be content without thinking itself right."

${ }^{28}$ Appearance and Reality, p. xv. 
rather than from a serious intellectual endeavor, is found in a recent note of Bernard Bosanquet's. ${ }^{2 \theta}$ Bosanquet, who through labored volumes loses human experience and values in a conceptual Absolute at their close, Bosanquet, whose "inmost aspiration" ${ }^{30}$ was, and is, to be able to say to the "critics of Absolutism": "Mark now, how a plain tale shall put you down,"-even Bosanquet has here told so plain a tale as to justify the feeling that the Absolute may be brought down as effectively by its friend as by its enemies. Bosanquet, surveying the Studio, feels an obvious impatience with those who (following his own footsteps) would push values out of human experience. "In a world of supreme values, wholly beyond doubt," he found himself saying, "What is the use of talking? Why do we not look?" There before him, the great apostle of the Absolute, were some pictures, "any one of them fit to bring heaven into our time and place." In that moment of insight, he confesses, "that the inexhaustibleness of values, of human experience, is altogether beyond the need of reasoning," and the thought left him, as he further confesses, "a little indifferent to the precise remoter inferences which we may draw from it, and a little impatient of any discussion which implies that we are not constantly in presence of supreme realities and immeasurable values. (All italics mine.) This "Undesigned Coincidence," as Bosanquet entitles his brief note, furnishes further corroboration of the theory of value enunciated in the earlier pages of this paper. Undesigned these corroborations are, but perhaps of greater weight because they are designed; for they indicate an unbiased recognition of just such a state of reality as Dewey's theory of value has so logically elaborated.

${ }^{20}$ The Philosophical Review, $30: 216$.

so The Principle of Individuality and Value, p. vi. 


\section{IV}

If one must have in every philosophy a metaphysics, I wonder if we might not call Dewey's theory of value, his metaphysics? This is suggested to me by the discovery that Dewey is treating in his theory of immediate values what those who have monopolized the term "metaphysics" treat under that head. The Absolute is the metaphysical object, par excellence; and Dewey also has his doctrine of the absolute or of absolutes. Every act of thinking finds its specific absolute in the restored immediate experience to which the act is instrumental. Immediate experience is absolute in the sense that it is the end of the problematic situation, and as such is consequently "invaluable." $81 \mathrm{Im}$ mediate experience enjoys the same surcease from the exigencies of thinking as does Bradley's Absolute. It seems to me that all the really distinctive and valuable attributes of the historical Absolute is preserved in Dewey's absolute(s), for the doctrine of the Absolute (absolutists to the contrary notwithstanding) has ever been an effort to guarantee emotional satisfaction through the procedure of rationalization. Dewey guarantees it, not by rationalizing, but by recognizing it for what it is and setting about with scientific foresight to make it permanent. In short, Dewey has succeeded in showing how within human experience itself, thought, instead of breeding vast contradictions through its relational nature, is, in the ascent of man, the instrument evolved for the resolution of the difficulties that arise on a lower level. Thought, precisely because it is relational, is the one means through which the absolute(s), which we so much prize, may retain their absoluteness; i. e., may remain unproblematical.

81 See Reconstruction in Philosophy, p. 175. 
I wish now to return briefly to Dewey's own theory in order to consider what seems to me the most significant objection made to it, an objection raised curiously enough not more by critics than by Dewey himself. Dewey's theory of value, as we have seen, calls for a dichotomy within experience; i. e., appreciation and reflection. But do these actually exist, separated from each other, as the discussion seems to imply? However appreciative it may be, is not all experience judgmental, implicitly at least? It is too easy to beg the question with the use of the term "implicit." That all experience, however purely appreciative, may (and does) become judgmental on occasion, Dewey both admits and affirms. Moreover, he explains what is "the occasion." But if the critics should affirm that all experience is actually judgmental, they would be doing no more than Dewey himself seems more than once to admit. ${ }^{32}$ With this admission one might still maintain that these two aspects-judgmental and appreciative-predominate in different situations, as Dewey himself affirms. But once admit that all experiences are all the time actually infected with more or less of the judgmental aspect, it seems to me that the distinction loses much of its significance. It may still be justified as an explanatory device, but it can no longer be sharply descriptive of actual experiences. Believing that the division is not only explanatory but accurately descriptive of human experience as well, I do not feel that Dewey need make the admission (if the passages quoted below and other similar ones constitute an admission. $)^{\text {ss }}$

32 "No experience having a meaning is possible without some element of thought. But we may contrast two types of experience, according to the proportion of reflection found in them." (Democracy and Education, p. 169.)

s8 "That something of the cognitive ... enters in as a catalyzer ... in even the most aesthetic experiences, seems to be altogether probable." (Lagic. p. 394.) 
The fact that one is always (during waking hours) thinking, leads too easily to the conclusion that all our experiences are more or less thought experiences. True, of course, that all our experiences are thought experiences while they are being thought about. But the question really is: Are all our experiences all the time being thought about? It seems clear to me that they are not, even to the degree that Dewey thinks probable. Thinking is never of things in general, never überhaupt. To the contrary, thinking is always quite utterly specific, as Dewey has repeatedly emphasized. Ignoring the apparent facts of sleey (in which one may afterwards distinguish satisfactory or unsatisfactory rest, though he remember not so much as a dream during the sleeping period), I should say that, since thought is genuinely specific, one is always $e x$ periencing more than he is thinking about; and this "more" (though it may at any time through developing disharmonies become the object of judgment) is for the time being experienced only appreciatively. ${ }^{84}$ To use Dewey's illustration, I may value my meal while evaluating the argument of my friend; or I may evaluate grit in my bread while valuing the presence of my friend. It seems to me that the two may not only be thought of as separate, but that they are actually quite separate; i. e., that Dewey's oft-repeated dichotomy does constitute a social and ethical metaphysics.

\section{T. V. Smith.}

The University of Chicago.

\footnotetext{
34 It is, I think, because he does not clearly recognize this that $\mathrm{Mr}$. Delton Thomas Howard in Dewey's Logical Theory (Cornell Studies in Philosophy, No. 11), is betrayed first into admitting that "it is doubtless true that men think only occasionally and with some reluctance" (p. 124), later into the declaration that "there is nothing in evidence to show that thinking is a special kind of activity, which operates now and then" (p. 127), and finally into the distinction that "the moment of real, earnest thinking is at the high tide of life, when all the powers are awake and operating" (p. 132).
} 